\title{
POTENTIAL FOR DEVELOPING TOURISM IN A SUB-REGIONAL GROWTH AREA (ROXAS-DUMARAN-TAYTAY) IN NORTHERN MAINLAND PALAWAN
}

\author{
RALPHAEL GONZALES ${ }^{1, *}$ and EDGAR M. REYES JR² \\ ${ }^{1}$ Philippine - Light Detection and Ranging 1 (Phil - LiDAR1), University of the Philippines Los Baños, 12822, Mayondon, \\ Los Baños Laguna, Philippines, 4030 \\ ${ }^{2}$ Department of Community and Environmental Resource Planning, University of the Philippines Los Baños, 12822, Mayondon, \\ Los Baños Laguna, Philippines, 4030 \\ *Corresponding author: rpgonzales1@up.edu.ph
}

\begin{abstract}
The majority of the tourism industry on mainland Palawan is located in the north of the province. El Nido and Puerto Princesa are the most visited tourist areas in Palawan. The municipalities between these areas are considered to be sub-regional growth areas (Roxas, Dumaran and Taytay) since they serve as transition areas from one tourist hot spot to another. This study explores the tourism potentials of the sub-regional groregionwth areas using a potential analysis. By exploring the cases of Roxas, Dumaran and Taytay, various potentials were identified that could contribute to the development of this region of the island. Characterization resulted in the identification of the competitive advantages of each municipality, which were used to develop this region in a way that assures a sustainable growth of this subregion that complements that occurring in the tourist hot spots.
\end{abstract}

Keywords: potentials analysis; tourism development; tourism growth poles; tourism spatial strategy

\section{Introduction}

Palawan is the largest province in the Philippines, with a total land area of $1,703,705$ hectares comprised of 1,708 islands and islets. It is dubbed as the "Last Ecological Frontier" in this country because of its unique and diverse flora and fauna (Sandalo and Baltazar 1997). Furthermore, this province is subdivided into three areas: northern Palawan, where the production of agricultural crops and tourism are important; southern Palawan, where agribusiness is most important; and in the middle is the lone city of Puerto Princesa, where most of the thriving industries (e.g. malls, call centres, factories, etc.) are located.

Palawan is one of the island provinces in the Philippines, where tourism and agriculture are important features of the economy. Based on data from the Palawan Tourism Promotions and Development Office (PTPDO), a total of 870,478 tourists visited the area in 2013 , which is $67.48 \%(587,441)$ greater than in 2008. The majority of the tourism industries in Palawan are located in the northern part of the province in which the municipality of El Nido and Puerto Princesa city are situated. In the 2013 the ranking of Puerto Princesa City and the municipality of El Nido were, respectively, first and third of the most visited sites in Palawan (Salcedo 2015). These municipalities offer different tourism-related activities, such as accommodation, leisure, food, tours and sightseeing.

Due to that fact, this city and municipality are the primary tourist hot spots based on the growth pole theory formulated by Francois Perroux in the early 1950s, which emphasizes in particular the importance that economic growth in a region should be linked with a key industry that has interconnections with different industrial activities and affects the area by promoting economic development (e.g. increase in employment, high labor force, expansion of existing industries, etc.) (Wheeler et al. 1998). Based on this theory, the city of Puerto Princesa and municipality of El Nido were identified as growth center's since based on various planning documents such as the National Tourism Strategy of the Philippines, Regional Development Plan and Provincial Physical Framework Plan of Palawan, include these municipalities in the primary tourism hot spots.

Furthermore, a study was conducted at Coron and Busuanga, another part of the province, where new tourist areas were developed to complement the growth of the primary tourist hot spots. These tourist areas are expected to gradually develop their own market and attract more visitors into the region (Tomeldan 2009).

However, the presence of tourism hot spots also connotes disparity through the phenomenon called polarization in which the majority of the economic activity occurs in the center of the region resulting in regional disparity (Balisacan 2006). In the case of northern mainland Palawan, the municipalities of Roxas, Dumaran and Taytay are sub-regional areas. They are characterized by having a lower capacity for development than the tourist hot spots, in lacking an urban center, a need to improve transport and infrastructural facilities and diversify the local economy by utilizing the rich and varied environmental assets of the rural settlements (Government Office for the East Midlands 2005).

This study focuses on the identification and classification of the potentials for developing tourism in the municipalities of Roxas, Dumaran and Taytay as part of the established tourism hot spots. The development of tour- 
ism in the sub-regional growth area (Roxas, Dumaran and Taytay) needs to be based on strategies that complement the development of tourism on the northern mainland, Palawan. This could result in more even growth in tourism in the province.

\section{Methodology}

This study included four municipalities and a city. At this scale it can be achieved by utilizing the primary and secondary data available (Johnston 2014) in different local government offices in each municipality and city and from the databases of provincial and national governments. The secondary data gathered was validated by a Key Informant Interviews (KII).

In terms of role clarification and assignment for the sub-regional area of growth, identifying its competitive advantages relative to those of the tourist hot spots sets the baseline for the competitive advantage of the tourist hot spots. The criteria for the identification were based on the Comprehensive Land Use Plan (CLUP) of the
Housing and Land Use Regulatory Board (HLURB) in the Philippines (Table 1).

These success factors emphasize the importance of competitive indicators such as natural environment, infrastructure, social services, etc., which affect the survival of the industry in the market (Thompson et al. 2012). By doing so, the ability of the sub-region to produce a unique industry that has the potential to become a regional development was highlighted. In addition, determination of strengths and weaknesses as assets of the sub-region unveils different potentials that contribute to the determination of competitive advantage (Blackwell and Eppler 2014).

Such data were combined and used in a tool called Potentials analysis. Potentials analysis is a planning and decision making tool that allows the creative and self-reflective analysis of the actual (already developed) and latent (existing but yet to be developed) resources within an area or community under study. This determines various potentials of a certain region resulting in a context based planning that is not dependent on external sources. This tool, utilizes different characteristics of an area,

Table 1 Criteria for evaluating tourism competitiveness (HLURB, 2014).

\begin{tabular}{|c|c|c|c|}
\hline Group heading & Criteria & Weight & Considerations \\
\hline \multirow[t]{2}{*}{ Lodging and Food } & Lodging facilities & $12 \%$ & Hotels, inns, resorts, private homes \\
\hline & Food facilities & $6 \%$ & Restaurants, drive in inns \\
\hline \multirow{5}{*}{$\begin{array}{l}\text { Recreation } \\
\text { and Shopping }\end{array}$} & Shopping facilities & $3 \%$ & Handicraft stores, gift shops, department stores \\
\hline & Night time recreation & $2 \%$ & Nightclubs, discotheques, theatres, cinema \\
\hline & Facilities conducive of health and relaxation & $2 \%$ & $\begin{array}{l}\text { Hot springs, mineral water springs, picnic grounds, } \\
\text { hiking trails, parks }\end{array}$ \\
\hline & Education facilities & $2 \%$ & Zoos, botanical gardens, aquariums, museums \\
\hline & Sports facilities & $2 \%$ & $\begin{array}{l}\text { Hunting, fishing, scuba diving, swimming, golf, } \\
\text { Tennis, Pelotas, horseback riding }\end{array}$ \\
\hline \multirow{3}{*}{$\begin{array}{l}\text { Infrastructure } \\
\text { and Utilities }\end{array}$} & Accessibility & $6 \%$ & Highways, roads, airports, bridges, piers \\
\hline & Transportation facilities & $6 \%$ & Land, sea, air facilities \\
\hline & Communication facilities & $4 \%$ & Radio, TV, telephone, Telegram \\
\hline \multirow[t]{2}{*}{ Natural factors } & Natural beauty & $15 \%$ & $\begin{array}{l}\text { General topography of the area, flora and fauna, } \\
\text { lakes and river, sea, island, springs, waterfalls }\end{array}$ \\
\hline & Climate & $5 \%$ & Amount of sunshine, temperature, fresh air \\
\hline Peace and order & Security for tourists & $10 \%$ & \\
\hline \multirow[t]{5}{*}{$\begin{array}{l}\text { Social and Cultural } \\
\text { factors }\end{array}$} & Artistic and architectural features & $2 \%$ & $\begin{array}{l}\text { Local architecture - mosques, monuments, old } \\
\text { buildings, forts }\end{array}$ \\
\hline & Festivals & $4 \%$ & Religious, sports, music/dance festivals \\
\hline & Distinctively local & $2 \%$ & Folk dances, costumes, music, souvenirs \\
\hline & Fairs and exhibits & $2 \%$ & Commercial/non-commercial \\
\hline & Attitude towards tourists & $2 \%$ & Local congeniality and treatment of tourists \\
\hline \multirow[t]{2}{*}{ Historical } & Ruins & $4 \%$ & Condition and accessibility \\
\hline & $\begin{array}{l}\text { Monuments, memorials, religious and historical } \\
\text { landmarks }\end{array}$ & $4 \%$ & $\begin{array}{l}\text { The extent to which a site may be well known due } \\
\text { to important historical events }\end{array}$ \\
\hline \multicolumn{4}{|c|}{$\begin{array}{l}\text { Rating: } \\
\text { Score in terms of points Descriptive Rating } \\
91-1003.1-4 \text { Excellent } \\
80-902.1-3 \text { Very Satisfactory } \\
66-791.1-2 \text { Satisfactory } \\
65-\text { below } 0.1-1 \text { Unsatisfactory }\end{array}$} \\
\hline
\end{tabular}


such as existing human resources and infrastructure to reveal the different potentials of a region.

Application for development in tourism is new and limited to unpublished manuscripts, however, this tool is widely used as it can elicit endogenous landscape characters that can be directly tapped and used to achieve the local or regional goals. Such purposes were similarly applied to the identified sub-regional growth centers in Northern Mainland Palawan. Consisting of simple potentials (e.g. mountains, rivers, etc.), this could become a more complex idea by combining two simple potentials that could result in first level potentials (e.g. mountain + river as source of water $=$ timber production), and combining a simple potential with a first level potential could result in a second level potential (e.g. humans as workers + timber production $=$ timber exportation). After this, the results from the first level potential and second level potential can be combined and analyzed in order to formulate a potential tourism development strategy for certain sub-regional growth areas. This resulted in the development of unique potentials that could be used to enhance regional development. Below is the step-by-step process for formulating a tourism development strategy using potentials analysis (Fig. 1).

\section{Results and Discussion}

\section{Analyzing the existing roles of the sub-regional growth area (Roxas-Dumaran-Taytay)}

The identified growth poles with the characters of Francois Perroux growth poles of 1988 indicate that a propulsive industry in one location can encourage growth outward from that location. Such industry, which in this case is tourism on the Northern-Mainland, Palawan. The thriving tourism in the area is generally coupled with a concentration of population and centralization of economic activities and services. The following are the observable characteristics of both the growth poles and growth centers in the regional analysis.

\section{Population character}

The an annual population growth rate of $4.51 \%$ and $3.32 \%$, for Puerto Princesa city and El Nido, respectively, clearly indicates that these municipalities are the growth centres in northern mainland Palawan, where the majority of the economic activity, especially tourism and other industries, are situated (Table 2). Unlike Roxas (2.59\%) and Dumaran $(2.67 \%)$, Taytay has a higher growth rate (3.10\%) because this municipality has more established

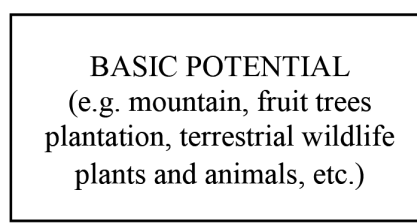

FRUIT TREES PLANTATION

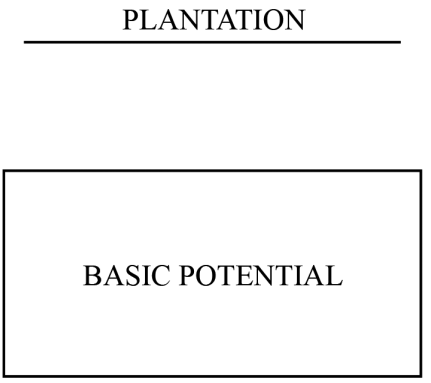

FRUIT TREES

PLANTATION
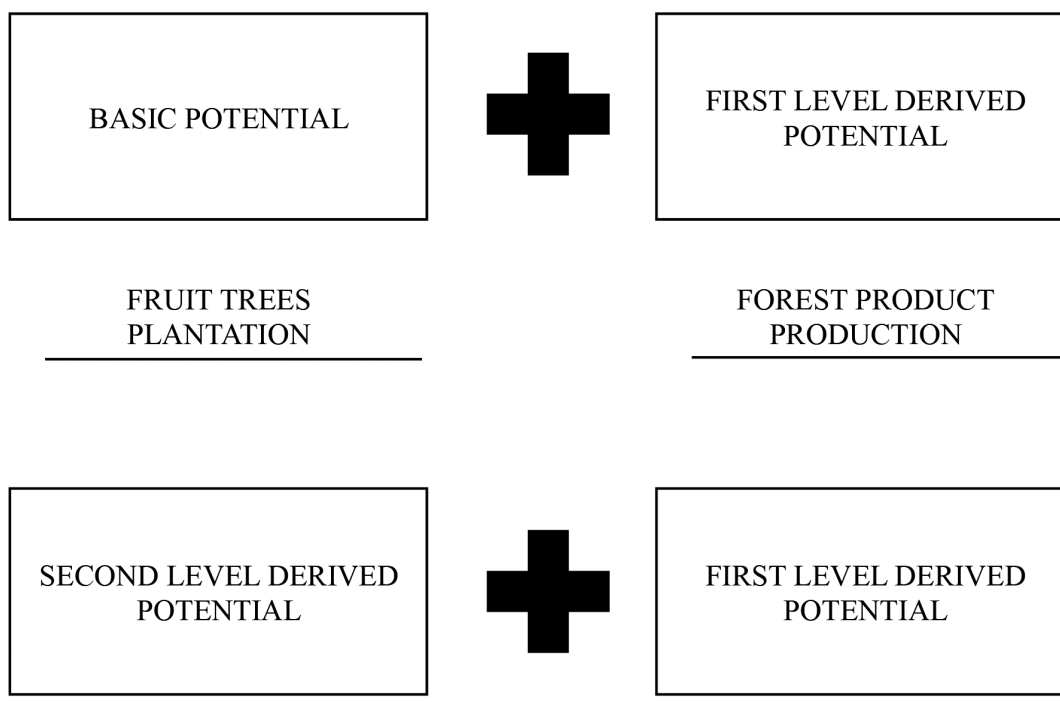
(e.g. mountain, fruit trees plantation, terrestrial wildlife plants and animals, etc.)

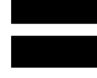

MOUNTAIN

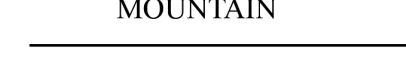

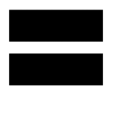

FOREST PRODUCT PRODUCTION
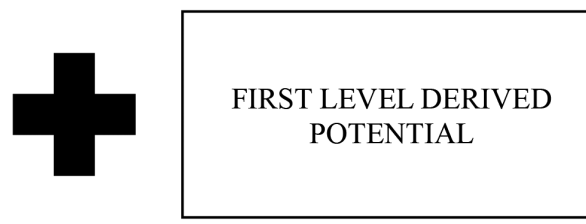

MARKETING OF PROCESSED FOOD PRODUCTS
FIRST LEVEL DERIVED POTENTIAL

(e.g. forest product production, post harvest food processing, small scale businesses, etc.)

FOREST PRODUCT PRODUCTION

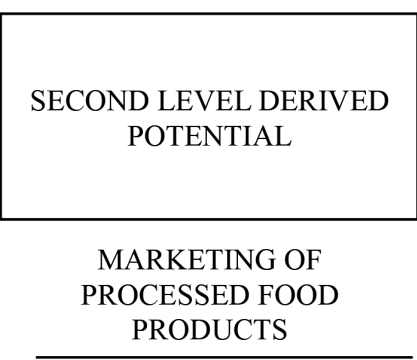

POTENTIAL TOURISM DEVELOPMENT STRATEGY

AGRO-ECOTOURISM AS

POTENTIAL TOURISM DEVELOPMENT STRATEGY

Fig. 1 Step-by-step process of Potentials analysis. 
Table 2 Historical population growth in the sub-regional growth area and tourism growth poles.

\begin{tabular}{|c|c|c|c|c|c|c|}
\hline \multirow{2}{*}{ Municipality } & \multicolumn{5}{|l|}{ Population } & \multirow{2}{*}{ Average Annual Growth Rate } \\
\hline & 1990 & 1995 & 2000 & 2005 & 2010 & \\
\hline Roxas & 36,604 & 44,370 & 47,242 & 51,084 & 61,058 & $2.59 \%$ \\
\hline Dumaran & 12,624 & 13,980 & 16,616 & 18,737 & 21,397 & $2.67 \%$ \\
\hline Taytay & 38,435 & 47,095 & 53,657 & 61,991 & 70,837 & $3.10 \%$ \\
\hline El Nido & 18,832 & 21,948 & 27,029 & 30,249 & 36,191 & $3.32 \%$ \\
\hline Puerto Princesa & 92,147 & 129,577 & 161,912 & 210,508 & 222,673 & $4.51 \%$ \\
\hline
\end{tabular}

economic characteristics as it was once the provincial capital of Palawan. Clearly, the population growth over the last two decades (1990s) in El Nido and Puerto Princesa has been higher and coincides with when tourism became important in Palawan.

\section{Population density}

Population distribution in the municipalities in this sub-regional growth area indicates that there are a few places where the population is dense enough to affect the level of productivity (Parr 1999). Taytay has a total population density of 55 persons $/ \mathrm{km}^{2}$ and the largest land area $\left(1,265.24 \mathrm{~km}^{2}\right)$, and a total population of 70,837 , followed by Roxas with a population density of 49 persons $/ \mathrm{km}^{2}$ in an area of $1,225.50 \mathrm{~km}^{2}$. Comparatively, there is only a slight difference between the characteristics of Roxas and Taytay. Lastly, Dumaran has the lowest population density of the municipalities with a total of 38 persons $/ \mathrm{km}^{2}$, which is lower than Roxas and Taytay, but its land area of $553.27 \mathrm{~km}^{2}$ is considerably less and as a consequence the population density there is much higher than in the other two municipalities (Dacumos 2015).

\section{Socio-economic character}

Puerto Princesa city and El Nido have higher annual population growth rates than that of the sub-region, which is a result of the agglomeration there of economies. This leads to the availability of social services geared towards accommodating the larger population and the influx of tourists. Also, being the centre of tourism (Puerto Princesa city and El Nido), the economic investment increases, which further increases the density of the population (Syez 2013). For instance, records of unemployment in Roxas and Taytay in 2010 are $56.97 \%$ and $73.28 \%$, respectively (SEP 2010), which are very high.

\section{Spatial stratification}

Based on the Provincial Development and Physical Framework Plan (HLURB 2014), municipalities in this sub-region are designated as agriculture - based economies, which produce major crops, livestock, poultry and fisheries. On the other hand, given the potential for an agriculture-based economy, the majority of the growth is in tourism and urban development. This is an example of spatial discrimination in which the potential role of a certain region is overridden by economic activity (Parr 1999).

\section{Market orientation}

Agricultural production of this sub-region mainly goes to centres of tourism in the province. Roxas' and $\mathrm{Du}-$ maran's cashew production goes directly to Puerto Princesa and is used to produce the booming cashew souvenir goods. Dumaran's livestock and Taytay's fish products, respectively, go mainly to hotels and restaurants in Puerto Princesa. This is also true of some High-Value Commercial Crops (HVCCs) and other vegetables produced only for the tourism industry.

These municipalities, by virtue of the growth pole strategy, are inevitable recipients of the "spillover" economic benefits (and possible negative effects) and services found in the growth centres since they have the services and investments for further development.

\section{Implications of the tourism growth poles}

The Spread and associated effects, as outlined by economists Myrdal and Hirschman,are among the general categories predicted by the growth pole theory. In the simplest sense, the spread effects are the positive effects of urban proximity for communities, and associated effects are the negative consequences of proximity. Several studies have revealed a variety of results if this theory is used as a guiding principle in explaining certain economic phenomena in the region.

Provided with such conditions, the northern mainland Palawan region was analyzed using the spread and associated effects predicted by the growth pole theory. In summary, the spread and associated effects can be measured by either a change in population or change in income as a function of distance to the nearest city (Ganning, n.d). Results show similarities in the effects of tourism growth poles in the region of Northern Mainland Palawan.

\section{Vibrant generation of employment in the growth poles}

Man-power coming from the sub region is employed in Puerto Princesa. Benefits from manual labour do not go to the municipality but the growth poles, as the demand is there. As for the case of Dumaran, all the vocational school graduates funded by the national government are employed in either Puerto Princesa or El Nido. Business and industry struggle to survive because they lack effective manpower, financial resources and 
investment, which mainly go to the more profitable areas (Puerto Princesa and El Nido), this unfavorable socio-economic context may also determine the level of entrepreneurship in an area (Chouinard et al. 2002).

\section{Population composition}

Employment associated with tourism attracts much of the local population to the growth poles and they also choose to reside near their place of work. Other aspects of this sub-regional population migration account for the services that only Puerto Princesa provides.

\section{Agricultural productivity}

Attraction is evident since the growth poles offer a larger market. Also, some areas in the sub-region, especially Dumaran, are the exclusive supplier of livestock and vegetables for Puerto Princesa for their booming tourism industry, even if there is a demand for similar products in the same municipality. Agriculture is important in Dumaran, Roxas and Taytay, accounting for 70\%, $70 \%$ and $72.36 \%$ of their economies, respectively (SEP 2010). This implies a strong dependence of the sub-regions on agriculture. In addition, the agricultural produce of the sub-region are raw materials devoid of added value, from which Puerto Princesa mainly profits.

\section{Poverty threshold}

The incidence of poverty is high in the sub-regional growth area because tourism attracts industries to northern mainland Palawan, which attracts workers. These movements of people are further stimulated by privatization and deregulation of public areas such as islands, forestland and agricultural land, which among other factors have considerably reduced the number of jobs for the locals (Gant 2006). The majority (68.07\%) of the households in the sub-regional growth area classified as below poverty threshold, with a total number of 29,918 (ERMP 2015). Taytay has the highest percentage of households in this classification with 13,264 (76.54\%), followed by Roxas with 12,993 (66.49\%) and Dumaran with 3,661 $(43.02 \%)$. In addition, there are a great number of households classified as below the food threshold level in Taytay, Roxas and Dumaran, with 60.87\%, 52.69\% and $27.40 \%$, respectively.

\section{Critical disruption of ecosystem}

In the case of the sub-regional growth area, there is a conflict between environmental conservation and economic development. Resources from the marine ecosystem, such as fish are decreasing, in particular coral reefs in Dumaran are no longer highly productive due to over fishing, privately owned pearl farms limiting the access to coastal waters, the conversion of mangrove and forest lands to residential areas and the unsustainable practice of the Kaingin system (slash and burn), which is evident particularly in Taytay and Dumaran. These activities are centered mostly on producing goods for the growth centers.

\section{Competitive advantage of tourism in the sub-regional growth area}

The figures in Table 3 provide an assessment of the competitive advantage of tourism in the sub-regional growth area (Roxas-Dumaran-Taytay). This is based on the capability of each sub-regional center to attract tourists to their area. Overall, of the three centers Taytay has the highest rating for tourism competitiveness although

Table 3 Researcher's evaluation of the tourism competitiveness in the sub-regional growth area.

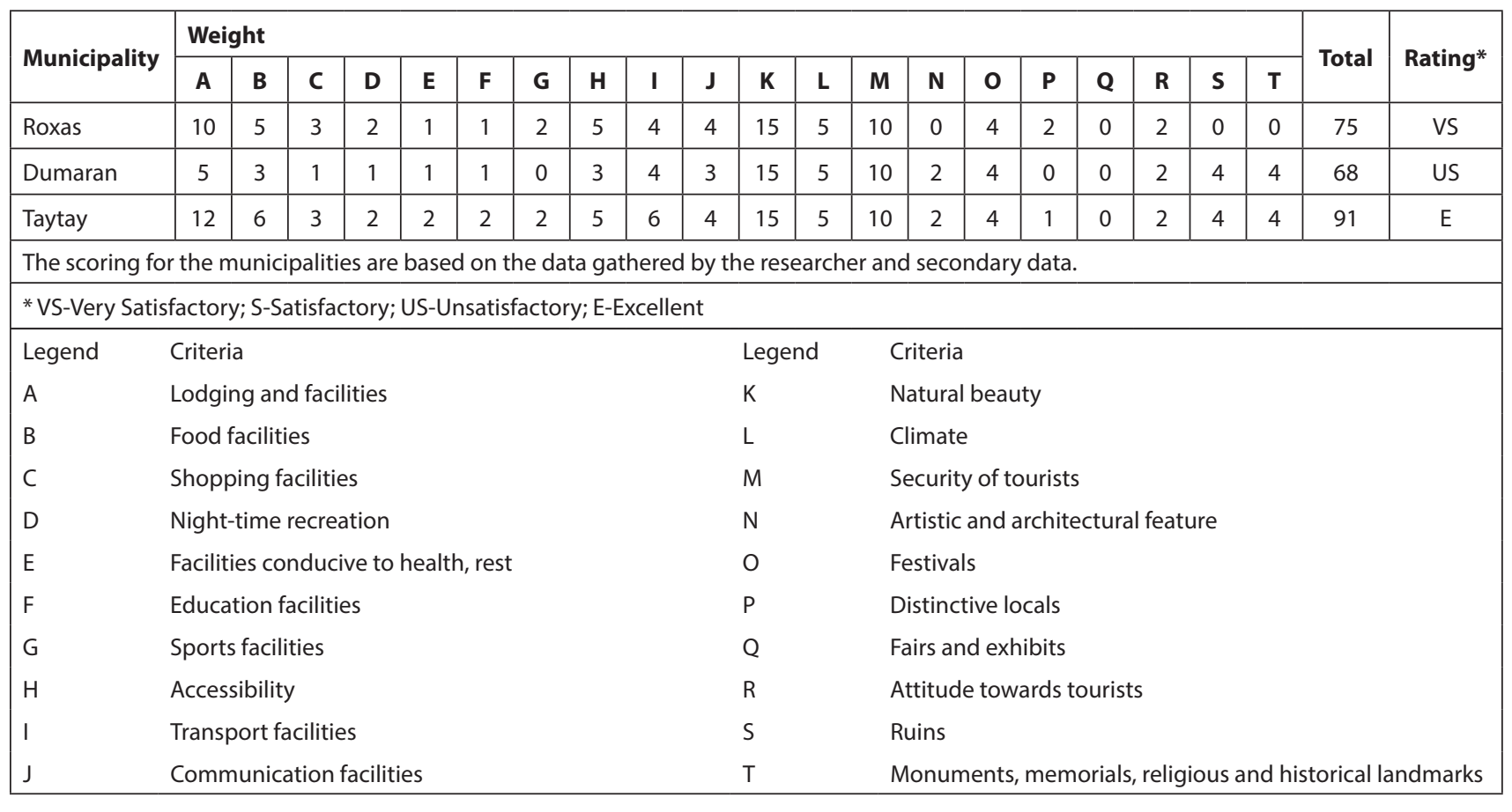


Roxas has also a high rating, but its competiveness is limited by lacking a plan for tourism and the necessary infrastructure. Lastly, the competiveness of Dumaran is the lowest, since it is just starting its tourism industry.

\section{Potential for developing tourism in the sub-regional growth area}

The table below shows the results of the Potentials Analysis of the municipality of Roxas, one of the sub-re- gional growth centres. The results for the other two municipalities (Dumaran and Taytay which were not shown on the table below) were also used to determine the regional strategy for the development of tourism. Using this process, the potential for tourism of each municipality was revealed and used in the development of tourism strategies that could be implemented.

In the case of the municipality of Roxas, the strategy focused on developing its agriculture sector and ecological aspects (islands, falls and wildlife). Other municipalities were similarly assessed and the results used to de-

Table 4 Basic potentials of the municipality of Roxas, Palawan.

\begin{tabular}{|c|c|c|c|c|}
\hline \multirow{9}{*}{ 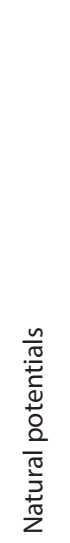 } & Code & Basic Potentials & Code & Basic Potentials \\
\hline & A1 & Mountains & A8 & Sand and other minerals \\
\hline & $\mathrm{A} 2$ & Forest products (herbal plants, honey, forest litter, hard wood) & A9 & Sea grass beds \\
\hline & A3 & Terrestrial wildlife and plants & A10 & Marine protected areas \\
\hline & A4 & Endemic and endangered species & A11 & Aquatic wildlife and plants \\
\hline & A5 & Waterfalls & A12 & Agricultural lands \\
\hline & A6 & Rivers & A13 & Islands and islets \\
\hline & A7 & Beach fronts & A14 & Seaweed \\
\hline & & & A15 & Cave \\
\hline \multirow{7}{*}{ 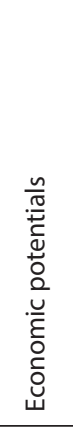 } & B1 & Agricultural production (rice, corn, etc.) & B8 & Seaweed production \\
\hline & B2 & Cashew production & B9 & Fish and aquaculture production \\
\hline & B3 & Fruit tree plantations & B10 & Van and bus transport \\
\hline & B4 & Livestock production & B11 & Private businesses \\
\hline & B5 & Small scale fishing activity & B12 & Money transfer facilities and pawnshop \\
\hline & B6 & Lodges and pension houses & B13 & Medium-to-large scale live fish trading \\
\hline & B7 & Poultry production & & \\
\hline \multirow{7}{*}{ 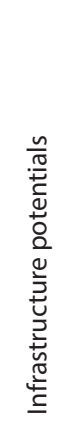 } & $\mathrm{C} 1$ & Bridge & $\mathrm{C} 8$ & Communication infrastructures \\
\hline & $\mathrm{C} 2$ & Ports & C9 & Government buildings and offices \\
\hline & $\mathrm{C} 3$ & Road networks & C10 & Agricultural facilites (mills, dryers, etc.) \\
\hline & $\mathrm{C} 4$ & Water supply system & C11 & Telecommunication facilities \\
\hline & C5 & Irrigation system & $\mathrm{C} 12$ & Reserved relocation site \\
\hline & $\mathrm{C} 6$ & Public facilities (halls, courts, etc.) & C13 & Airstrip \\
\hline & $\mathrm{C7}$ & Social infrastructures (church, schools, etc.) & & \\
\hline \multirow{3}{*}{ 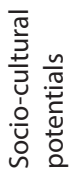 } & D1 & Peoples organizations & D4 & Traditional values, beliefs and practices \\
\hline & D2 & Sense of Ccommunity & D5 & Local language \\
\hline & D3 & Festivals and traditional social celebrations & & \\
\hline \multirow{4}{*}{ 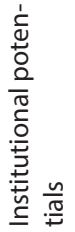 } & E1 & LGU livelihood support & E5 & Responsive line agencies \\
\hline & E2 & Development funds & E6 & Peace and order maintenance and support \\
\hline & E3 & Collaborative academic institutions & E7 & Provincial government support \\
\hline & E4 & NGOs and volunteers & & \\
\hline
\end{tabular}


velop their respective tourism strategies and to promote complementary growth based on their competitive advantages.

The determination of the basic potentials led to the formulation of derived potentials. These potentials were combinations of various basic potentials. These first level derived potentials were then combined with basic potentials, which resulted in second level derived potentials of the municipality of Roxas, Palawan. This was also done for the other two municipalities (Dumaran and Taytay).

\section{Conclusion}

The municipalities of Dumaran, Roxas and Taytay have the characteristics of peripheral areas associated with tourism growth poles on the northern mainland Palawan. Indicators such as population growth, population density, socio- economic character, spatial stratification and market orientation indicate that the municipalities of Roxas, Dumaran and Taytay are sub-regional growth areas as the growth in these municipalities is lower than in the growth poles.

All three municipalities in the sub-region studied suffered similarly (e.g. the greater employment prospects and standard of living in tourism hot spots were greater than locally, which resulted in a migration of people to the hot spots, over exportation of primary products and ecosystem disruption by supporting the continuous growth of the centres of tourism. Such implications include the positive economic gains for Puerto Princesa and El Nido in terms of their vibrant tourism industries, but more significantly, the inevitable negative effects on the established relationships in the sub-regional area (Dumaran-Roxas-Taytay), which resulted in economic losses from decrease in employment and a reduction in population and investments.

The continuous providing of agricultural and other primary products to Puerto Princesa and El Nido, resulted in the ecosystem in the sub-region (Dumaran-Roxas-Taytay) being severely damaged due to a demand-driven conversion and use of natural resources to augment the increasing demand for ecotourism services.

Table 5 First level derived potentials based on combinations of various basic potentials of Roxas, Palawan.

\begin{tabular}{|c|c|c|c|c|c|}
\hline Code & $\begin{array}{l}\text { First level derived } \\
\text { potentials }\end{array}$ & $\begin{array}{l}\text { Combination of basic } \\
\text { potentials to form first level } \\
\text { derived potentials }\end{array}$ & Code & $\begin{array}{l}\text { First level derived } \\
\text { potentials }\end{array}$ & $\begin{array}{l}\text { Combination of basic } \\
\text { potentials to form first level } \\
\text { derived potentials }\end{array}$ \\
\hline F1 & $\begin{array}{l}\text { Processing of cashew into } \\
\text { butter }\end{array}$ & $\mathrm{A} 3, \mathrm{~B} 2, \mathrm{D} 1, \mathrm{E1}, \mathrm{E} 5$ & F14 & $\begin{array}{l}\text { Establishment of private } \\
\text { business groups }\end{array}$ & $\mathrm{B} 6, \mathrm{~B} 7, \mathrm{~B} 11, \mathrm{~B} 12, \mathrm{~B} 13$ \\
\hline F2 & $\begin{array}{l}\text { Improved farm-to-market } \\
\text { roads }\end{array}$ & $\mathrm{A} 8, \mathrm{C} 3, \mathrm{C} 4, \mathrm{D} 1, \mathrm{E} 2, \mathrm{E} 7$ & F15 & $\begin{array}{l}\text { Establishment of tourism } \\
\text { information center }\end{array}$ & $\mathrm{A} 8, \mathrm{C} 6, \mathrm{C} 7, \mathrm{C} 8, \mathrm{E} 2, \mathrm{E} 4, \mathrm{E} 5, \mathrm{E} 7$ \\
\hline F3 & $\begin{array}{l}\text { Improved management of } \\
\text { MPAs }\end{array}$ & $\mathrm{A} 4, \mathrm{~A} 10, \mathrm{D} 1, \mathrm{E3}, \mathrm{E} 4, \mathrm{E} 7$ & F16 & $\begin{array}{l}\text { Development of small } \\
\text { scale business enterprises }\end{array}$ & E5, E7, B11 \\
\hline F4 & $\begin{array}{l}\text { Inventory of wildlife } \\
\text { species (flora and fauna) }\end{array}$ & $\begin{array}{l}\text { A3, A4, A10, A11, D1, D3, E3, } \\
\text { D4, E6, E7 }\end{array}$ & F17 & Biodiversity Showcase & $\begin{array}{l}\text { A3, A4, A8, A9, A10, A12, A13, } \\
A 14, E 3, E 4, E 5, E 7\end{array}$ \\
\hline F5 & $\begin{array}{l}\text { Active, diversified, } \\
\text { empowered and well } \\
\text { organized community } \\
\text { groups }\end{array}$ & D1, D2, D3, E3, E4, E5, E7 & F18 & $\begin{array}{l}\text { Nursery/ mass propagation } \\
\text { of economic plants }\end{array}$ & $\mathrm{A} 2, \mathrm{~A} 3, \mathrm{~A} 4, \mathrm{E} 3, \mathrm{E} 4, \mathrm{E} 5, \mathrm{E} 7$ \\
\hline F6 & $\begin{array}{l}\text { Forest products production } \\
\text { (honey, forest litter, rattan, } \\
\text { etc.) }\end{array}$ & $\mathrm{A} 2, \mathrm{~A} 14, \mathrm{D} 1, \mathrm{D} 2, \mathrm{E} 1$ & F19 & $\begin{array}{l}\text { Integration of municipal } \\
\text { plans }\end{array}$ & E2, E3, E7 \\
\hline F7 & Crop producers' cooperative & $\mathrm{B} 1, \mathrm{~B} 2, \mathrm{~B} 3, \mathrm{D} 1, \mathrm{D} 2, \mathrm{E} 2, \mathrm{E} 4$ & $\mathrm{~F} 20$ & $\begin{array}{l}\text { Active research on } \\
\text { identification of other } \\
\text { possible tourism sites }\end{array}$ & $\begin{array}{l}\text { B6, B9, D2, D3, D4, D6, E3, E4, } \\
\text { E5, E7 }\end{array}$ \\
\hline F8 & Fish community cooperative & $\mathrm{B} 5, \mathrm{~B} 7, \mathrm{~B} 8, \mathrm{D} 1, \mathrm{D} 2, \mathrm{E} 2, \mathrm{E} 4$ & $\mathrm{~F} 21$ & $\begin{array}{l}\text { Development of } \\
\text { marketing strategies for } \\
\text { local products }\end{array}$ & $\begin{array}{l}\text { B1, B2, B3, B5, B7, B8, B10, B12, } \\
\text { C7, D1, E1, E3, E4, E5, E7 }\end{array}$ \\
\hline F9 & $\begin{array}{l}\text { Livestock producers' } \\
\text { cooperative }\end{array}$ & B4, D1, D2, E2, E4 & $\mathrm{F} 22$ & $\begin{array}{l}\text { Improvement and } \\
\text { exploration of sustainable } \\
\text { sources of electricity }\end{array}$ & A5, A6, B1, D1, E2, E3, E5, E7 \\
\hline F10 & Post-harvest food processing & $\mathrm{B} 1, \mathrm{~B} 2, \mathrm{~B} 3, \mathrm{~B} 4, \mathrm{D} 1, \mathrm{E} 1, \mathrm{E} 5$ & F23 & Improve quality of water & $\mathrm{C} 4, \mathrm{E} 1, \mathrm{E} 2, \mathrm{E} 3, \mathrm{E} 4, \mathrm{E} 5, \mathrm{E} 7$ \\
\hline F11 & $\begin{array}{l}\text { Improved water supply and } \\
\text { irrigation system }\end{array}$ & C4, D1, E2, E7 & & & \\
\hline F12 & $\begin{array}{l}\text { Establishment of } \\
\text { conservation sites }\end{array}$ & $\begin{array}{l}\text { A3, A4, A8, A9, A10, A12, A13, } \\
A 14, E 3, E 4, E 6, E 7\end{array}$ & & & \\
\hline F13 & $\begin{array}{l}\text { Research collaboration for } \\
\text { tourism development }\end{array}$ & E3, E4, E5, E7 & & & \\
\hline
\end{tabular}


Table 6 Second level derived potentials based on the combination of basic potentials and the first level derived potentials of Roxas, Palawan.

\begin{tabular}{|c|c|c|c|c|c|c|c|}
\hline & Code & $\begin{array}{l}\text { Second level de- } \\
\text { rived potentials }\end{array}$ & $\begin{array}{l}\text { Combination of basic potentials } \\
\text { and first level derived potentials } \\
\text { to form second level derived } \\
\text { potentials }\end{array}$ & & Code & $\begin{array}{l}\text { Second level de- } \\
\text { rived potentials }\end{array}$ & $\begin{array}{l}\text { Combination of basic potentials } \\
\text { and first level derived potentials } \\
\text { to form second level derived } \\
\text { potentials }\end{array}$ \\
\hline \multirow{4}{*}{ 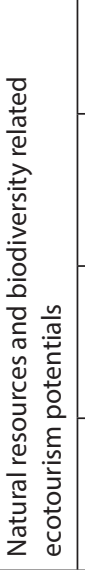 } & G1 & $\begin{array}{l}\text { Museum of } \\
\text { wildlife }\end{array}$ & $\begin{array}{l}\text { A1, A4, A13, C6, C7, C9, D1, D2, D3, } \\
\text { D6, D7, E1, E2, E3, E4. E5, E7, F3, F4, } \\
\text { F5, F12 }\end{array}$ & \multirow{5}{*}{ 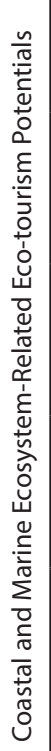 } & G9 & $\begin{array}{l}\text { Island/islets } \\
\text { adventure tour } \\
\text { packages }\end{array}$ & $\begin{array}{l}\text { A4, A9, A11, A12, A13, A14, A15, } \\
\text { A18, B13, C2, D3, E2, E5, F5, F8, F12, } \\
\text { F13, F15, F16, F20 }\end{array}$ \\
\hline & G2 & $\begin{array}{l}\text { Wildlife encounter } \\
\text { package }\end{array}$ & $\begin{array}{l}\text { A1, A3, A4, A11, B10, B11, C3, C6, } \\
\text { C7, C8, C9, C11, D1, E1, E2, E3, E4, } \\
\text { E5, E7, F4, F5, F12, F13, F14, F15, } \\
\text { F16 }\end{array}$ & & G10 & $\begin{array}{l}\text { Island living expe- } \\
\text { rience }\end{array}$ & $\begin{array}{l}\text { A4, A9, A11, A12, A13, A14, A15, } \\
\text { A18, D2, D3, E1, E4, E6, F5, F8, F12, } \\
\text { F13, F15, F19 }\end{array}$ \\
\hline & G3 & Falls tour package & $\begin{array}{l}\text { A1, A5, A6, B10, B11, B13, C3, C6, } \\
\text { C7, C8, C9, C11, D1, E1, E2, E3, E4, } \\
\text { E5, E7, F4, F5, F12, F13, F14, F15, } \\
\text { F16 }\end{array}$ & & G11 & $\begin{array}{l}\text { Kayaking and } \\
\text { boating }\end{array}$ & $\begin{array}{l}\text { A4, A9, A11, A12, A13, A14, A15, } \\
\text { A18, B13, E2, E7, F5, F8, F12, F13, } \\
\text { F16 }\end{array}$ \\
\hline & G4 & Bat watching & $\begin{array}{l}\text { A1, A13, A15, B10, B11, B13, C3, C6, } \\
C 7, C 8, C 9, C 11, D 1, E 1, E 2, E 3, E 4, \\
\text { E5, E7, F4, F5, F12, F13, F14, F15, } \\
\text { F16 }\end{array}$ & & G12 & $\begin{array}{l}\text { Coral reef snorke- } \\
\text { ling and diving }\end{array}$ & $\begin{array}{l}\text { A4, A9, A11, A12, A13, A14, A15, } \\
\text { A18, B13, D3, E2, E5, F5, F8, F12, } \\
F 13, F 15, F 16, F 20\end{array}$ \\
\hline \multirow{4}{*}{ 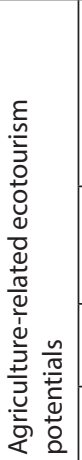 } & G5 & $\begin{array}{l}\text { Improvement and } \\
\text { diversi-fication of } \\
\text { poultry and live- } \\
\text { stock industry }\end{array}$ & $\begin{array}{l}\text { A2, A6, A10, A11, A12, A14, B1, B2, } \\
B 3, B 4, B 5, B 7, B 8, B 9, B 11, B 13, C 1, \\
C 2, C 3, C 4, C 5, C 10, D 1, E 1, E 2, E 3, \\
\text { E4, E5, E7, F1, F2, F3, F4, F5, F6, F7, } \\
\text { F8, F9, F10, F11, F16 }\end{array}$ & & G13 & $\begin{array}{l}\text { Countryside resort } \\
\text { living experience }\end{array}$ & $\begin{array}{l}\text { A4, A9, A11, A12, A13, A14, A15, } \\
A 18, B 13, C 2, D 2, D 3, E 2, E 5, F 5, F 8, \\
F 12, F 13, F 15, F 16, F 20, F 22\end{array}$ \\
\hline & G6 & $\begin{array}{l}\text { Marketing of } \\
\text { processed food } \\
\text { products }\end{array}$ & $\begin{array}{l}\text { B11, B12, B13, C11, E1, E2, E3, E4, } \\
\text { E5, E7, F14, F16, F18 }\end{array}$ & & & & \\
\hline & G7 & $\begin{array}{l}\text { Marketing of agri- } \\
\text { cultural crops }\end{array}$ & $\begin{array}{l}\text { B11, B12, B13, C11, E1, E2, E3, E4, } \\
\text { E5, E7, F14, F16, F18 }\end{array}$ & & & & \\
\hline & G8 & $\begin{array}{l}\text { Promotion of } \\
\text { cashew festival }\end{array}$ & $\begin{array}{l}\text { B2, D1, D2, D3, D4, D5, E1, E2, E3, } \\
\text { E4, E5, E7 }\end{array}$ & & & & \\
\hline
\end{tabular}

\section{Recommendations}

The creation of multiple tourism hot spots definitely promotes rural development as explained by the growth pole strategy (Parr 1999). The multiple tourism hot spots will keep up with the increasing needs of the existing tourism centres (Puerto Princesa city and El Nido) in terms of agricultural production while simultaneously creating complementary centres of tourism in the municipalities of Dumaran, Roxas and Taytay. The multiple centres of tourism growth in the sub-region will mimic the "One town one product" approach. The One Town, One Product (OTOP-Philippines) is a priority program of the government to promote entrepreneurship and create jobs (DTI 2011).

However, this strategy needs to be more radical in terms in creating an exemplary tourism service in the municipalities that is well-coordinated so that tourism in the sub-region is beneficial for all the participants. One such success involved a case where regional development was based on the expansion of recreational or tourist activity (Harper et al. 1966).

Although the sub-region has a competitive advantage over the growth poles there is an opportunity cost associated with it. This could be further utilized through a division of labor and specialization. Below are the advantages of the sub region in relation to growth poles (Table 7). Since the municipalities in the sub-region focus on agriculture, most of their competitive advantage is associated with agriculture. In addition, differences in their endemic species, historical sites and local products were also included in their competitive advantage.

In essence, the development of many centers of tourism may lead to sustained strong economic growth (Lin 2010). Since the sub-region has a competitive advantage over the growth poles, prioritization and strengthening of the potential could further reduce the gap between developments in the two regions.

Forest and marine fisheries will help the municipality of Dumaran to highlight its competitive advantage as it is endowed with rich and diverse forest and marine resources.

Roxas, as a largely agricultural economy and must focus on its flourishing agro-industry, promoting agro-ecotourism as its competitive advantage and add value and diversify its agricultural products.

Taytay on the other hand, must continue to supply fish to the province and also develop a fishing village industry. Also, its heritage potential undoubtedly could be an attraction for tourists.

These developments in the tourism industry will only be possible if the current state of their ecosystems is 
Table 7 Competitive advantages of the municipalities in the sub-regional growth area (Roxas-Dumaran-Taytay).

\begin{tabular}{|l|l|l|}
\hline $\begin{array}{l}\text { Sub-regional } \\
\text { Municipalities }\end{array}$ & Competitive advantage & Ecotourism potential \\
\hline Dumaran & Philippine cockatoo (Katala), WW-II ruins (shipwrecks), mangrove forest, Katala festival & Forest and mariculture \\
\hline Roxas & Cashew nuts, bat island, sand bar, fresh water turtle, cashew festival, falls & Agro-ecotourism \\
\hline Taytay & $\begin{array}{l}\text { Spanish fort, malampaya sound, irrawaddy dolphin, balinsasayaw cave, lagoons, limestone } \\
\text { formations, island formations, Spanish ruins, Spanish light house, Pasinggatan festival, white } \\
\text { squirrel, white sand beaches, lake, coral reefs, wildlife species, giant flying fox }\end{array}$ & Agro-marine ecotourism \\
\hline
\end{tabular}

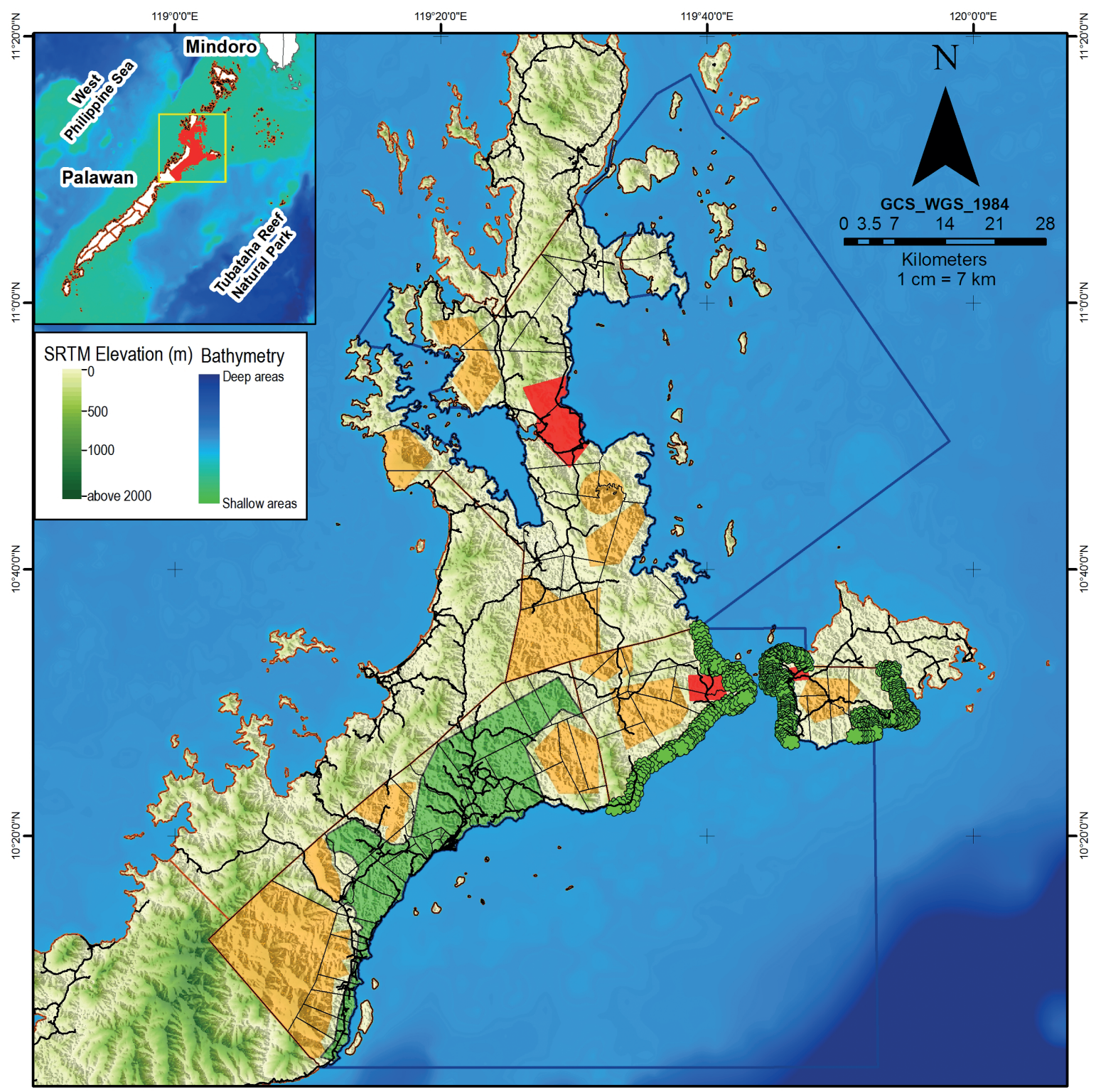

\section{Proposed Ecotourism Zoning Strategy of the Sub-Regional Growth Area of Northern Mainland, Palawan}

Prepared by: Ralphael P. Gonzales | November 22, 2015 | Source www. philgis.org

This is a proposed ecotourism zoning plan of the sub-regional growth area in Northern Mainland, Palawan. This has not undergone any validation nor ground truthing activities.

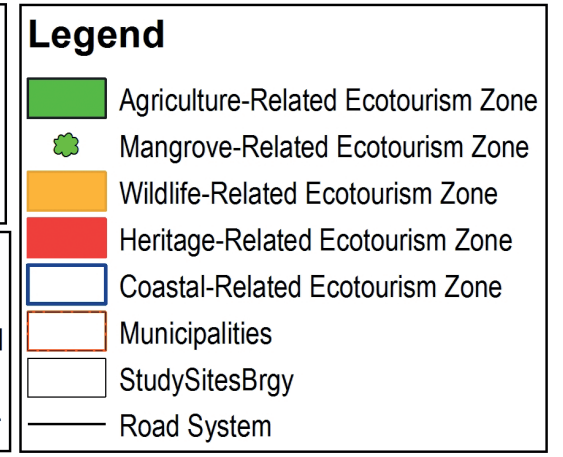

Fig. 2 Proposed development of tourism in the province of Palawan based on the results of the Potentials analysis. 
taken into consideration and proper community-based guidelines are established. In addition, to integrate the developments in Dumaran into this region's ecotourism.

For Roxas and Taytay, a specific regional level working group must be formed in order to coordinate their activities in relation also to the existing ecotourism industry of the whole northern Palawan region.

Regional tourism as a strategy is proposed in order to limit the increasingly negative effects of polarization of tourism associated with the developments in Puerto Princesa and El Nido. This strategy emanates from the growth pole concept, but to create multiple ecotourism growth poles that include the unique potential contributions of Dumaran, Roxas and Taytay will greatly complement the already existing tourism industry.

\section{REFERENCES}

Balisacan A, Hill H, Piza FAS (2006) Regional Development Dynamics and Decentralization in the Philippines: Ten Lessons from a 'Fast Starter'. Australian National University, Economics RSPAS, Departmental Working Papers. 25. 10.1355/AE25-3D.

Blackwell R, Eppler D (2014) An Approach to Strategic Situation Analysis: Using Models as Analytical Tools. J.G.B.M. 10: $80-85$.

Chouinard O, Desjardins PM, Forgues É (2002) Collective Entrepreneurship and Regional Development: Case Study of a New Brunswick Cooperative. JRC 30: 79-94.

Dacumos et al. (2015) ECAN Resource Management Plan of the municipality of Rox-as, Palawan. Technical Report. Supervised Field Experience. University of the Philippines.

Department of Trade and Industry (2011) One Town, One Product Program. http://www.dti.gov.ph/programs-projects/otop.

Gant U (2006) Urban Economic Growth and Poverty. Poverty Report 2008-2009. Chronic Poverty Research Centre. University of Wisconsin-Madison.

Government Office for the East Midlands (2005) Regional Spatial Strategy for the East Midlands (RSS8). The Stationary Office, Office of the Deputy Prime Minister, Great Britain, pp 56-58.
Harper RA, Schmudde TH, Thomas FH (1966) Recreation based economic development and the growth-point concept. Land Econ 42: 95-101.

Housing and Land Use Regulatory Board (HLURB) (2014) Comprehensive Land Use Plan Guide Book: Sectoral Analysis and Tool for Situational Analysis. Vol. 2.

Housing and Land Use Regulatory Board (HLURB) (2014-2023) Provincial Development and Physical Framework Plan, Palawan (2014-2024).

Johnston MP (2014) Secondary Data Analysis: A Method of Which the Time has Come. QQML 3: 619-626.

Lin YJ (2010) A Global Economy with Multiple Growth Poles. World Bank. doi: doi.org/10.1596/9780821385180_CH03.

Munasinghe M (2008) Economic, social, and environmental elements of development. Encyclopedia of Earth, http://www .eoearth.org/view/article/51cbed797896bb431f6926b4/.

Parr J (1999) Growth-pole Strategies in Regional Economic Planning: A Retrospective View. Part 1 Origins and Advocacy. Urban Stud 36: 1195-1215.

Salcedo AM (2015) A Model of Tourism Destination Choice: Palawan Province Case. PhD Thesis, School of Economics, University of Asia and the Pacific, Philippines.

Sandalo RM, Baltazar T (1997) The Palawan Biosphere Reserve (Philippines). Working Papers No. 19, Paris, France: UNESCO (South-South Cooperation Programme for Environmentally Sound Socio-Economic Development in the Hu-mid Tropics). http://unesdoc.unesco.org/images/0010/001092/109211eo.pdf.

Socio Economic Profile (2010) Socio-Economic Profile of the Province of Palawan. (Does not have an online source and the copy was only limited to the province of Palawan.)

Syez EW (2013) Growth Pole Theory as A Concept Based On Innovation Activity Development and Knowledge Diffusion. Przedsiębiorstwo we współczesnej gospodarce - teoria i praktyka 3: 17-33.

Thompson A, Peteraf MA, Gamble JE, Strickland, AJ (2012) Crafting and executing strategy: The quest for competitive advantage. New York: McGraw-Hill/Irwin.

Tomeldan M (2009) Tourism Structure Plan of Busuanga and Coron, Northern Palawan: Comprehensive Development through Tourism.

Wheeler J, Muller PO, Thrall GI, Fik TJ (1998) Economic Geography (3rd ed). Library of Congress Cataloging-in-Publication Data. John Wiley and Sons, Inc. 